http://dx.doi.org/10.12775/szhf.2018.007

\author{
Micha£ Koza \\ Uniwersytet Jagielloński, Kraków, Polska \\ e-mail: michal.koza@outlook.com
}

\title{
Osoba i nicość. Wolność w ujęciu Jana Pawła II i Jean-Paula Sartre’a
}

1. Drogi wolności - personalizm i egzystencjalizm

Niewiele idei w kulturze współczesnej jest uwikłanych w różnorakie spory tak bardzo jak pojęcie wolności. Myśliciele, wśród których pojawiają się nie tylko reprezentanci nauk humanistycznych, ale i przyrodniczych (czy również studiów interdyscyplinarnych), udzielają skrajnie odmiennych odpowiedzi na pytania związane $\mathrm{z}$ naturą fenomenu ludzkiego samostanowienia. Odbiciem tych różnic były wydarzenia historyczne, w których urzeczywistniły się zarówno najokrutniejsze formy zniewolenia (zwłaszcza w totalitaryzmach), jak i najbardziej wzniosłe (choć nie zawsze konsekwentne) ideologie rozszerzania granic wolności. Za tym zagadnieniem stoi bogata tradycja filozoficzna - jak zauważa Vittorio Possenti, „[...] problem wolności stanowi jeden z największych dylematów epoki nowoczesnej i być może był jej centralnym programem od Kartezjusza do Fichtego i Schellinga, od Kanta po Bergsona i Sartre’a. Jest on zarazem jednym z tych pytań, które pozostały wciąż otwarte przy przejściu od modernizmu do postmodernizmu”" . Do myślicieli, którzy

${ }^{1}$ V. Possenti, Filozofia i wiara, przeł. K. Kubis, Kraków 2004, s. 24. 
w sposób systematyczny podejmowali się próby zgłębienia kwestii wolności należy Karol Wojtyła. Podejmował ją w duchu chrześcijańskiego personali$\mathrm{zmu}$, łączącego i rozwijającego tradycje tomizmu i fenomenologii, dając wyraz swojej refleksji między innymi w dogłębnym studium Osoba i czyn.

Zainteresowanie wolnością jest obszarem, na którym myśl Wojtyły (a później papieża Jana Pawła II) spotyka się z filozofią egzystencjalistyczną. Należy ona do nurtów myśli europejskiej, które "programowo" kładą silny nacisk na znaczenie wolności, wskazując ją najczęściej jako główny aspekt podmiotowości. Stoi ona także w centrum filozofii Jean-Paula Sartre’a, autora Bytu i nicości, zaliczanego do ateistycznego nurtu myśli egzystencjalistycznej, a więc wychodzącego ze skrajnie odmiennych niż Karol Wojtyła założeń. Niemniej jednak porównanie koncepcji tych dwóch filozofów, mimo dzielących ich istotnych różnic, pozwala prześledzić dwie drogi humanistycznej refleksji zwłaszcza po to, by wskazać pewne miejsca wspólne, które pozwalają lepiej umiejscowić oba nurty na mapie zachodniej filozofii podmiotowości. Co więcej, wskazują też na wzajemne ich przenikanie się - w tej perspektywie personalizm Karola Wojtyły okazuje się tak naprawdę „osłabieniem metafizyki” (według określenia zaczerpniętego od Gianniego Vattimo²) scholastycznej poprzez podjęcie wątków fenomenologicznych, a zarzuty wobec Sartre’a o bycie zbyt uwikłanym w klasyczne, substancjalne myślenie stają się bardziej zrozumiałe.

\section{Wolność człowieka jako przeżycie - w stronę fenomenologii}

Z pewnością dość ogólnym i w miarę oczywistym miejscem spotkania będzie dla tych koncepcji stosunek do determinizmu. Według określenia samego Wojtyły kierują się one raczej w stronę „personalistycznego typu myślenia” niż „kosmologicznego”’3. Jak zaznacza Andrzej Półtawski:

${ }^{2}$ Por. G. Vattimo, Koniec nowoczesności, przeł. M. Surma-Gawłowska, Universitas, Kraków 2006.

${ }^{3}$ Por. K. Wojtyła, Podmiotowość i „to, co nieredukowalne” w człowieku, [w:] Osoba i czyn oraz inne studia antropologiczne, red. T. Styczeń, W. Chudy, J. W. Gałkowski, A. Rodziński, A. Szostek, Lublin 2000, s. 440; R. K. Wilk, Metodologia antropologii filozoficznej Karola Wojtyły, „Kwartalnik Filozoficzny”, red. W. Stróżewski, t. XXXVIII, 2010, z. 2, s. 40-41. 
dla takiego kosmologicznego podejścia to, co w człowieku nieredukowalne, pozostaje pustym miejscem, które może być wypełnione właściwą treścią dopiero przez badanie zorientowane personalistycznie. Dlatego, podkreśla Wojtyła, trzeba wypełnić to puste miejsce. [...] Kluczowym zadaniem jest zatem zrozumienie człowieka jako mogącej się rozwijać osoby ${ }^{4}$.

W tym „pustym miejscu” filozof proponuje umiejscowić świadomość, „człowieka jako konkretne «ja», jako przeżywający siebie podmiot”, którego struktury możemy odkrywać w fenomenologicznej analizie źródłowego przeżycia, zawartego w doświadczeniu „człowiek działa”. Mimo że filozof nie odrzuca wartości podejścia kosmologicznego, zaznacza, iż sedno prawdy o człowieku kryje się w korzystającej z dorobku fenomenologii refleksji nad personalistycznym wymiarem człowieczeństwa.

Fenomenologiczna (a więc udzielająca się w doświadczeniu, „jawiąca się") jedność osoby i czynu stanowi dla Wojtyły powód nierozdzielnego sprzężenia wolności z podmiotowością. Pojęcie osoby, wyrażające całość tej rzeczywistości podmiotowej w duchu ontologicznego realizmu, ma decydujące znaczenia dla postrzegania wolności człowieka przez pryzmat pozytywności i afirmacji. Wolność, przysługująca osobie, jest zdaniem Wojtyły zakorzeniona $\mathrm{w}$ bycie - określonym i posiadającym trwałe struktury, będące metafizycznym fundamentem ludzkiej możliwości działania, zgodnie z zasadą operari sequitur esse ${ }^{6}$ („działanie jest następstwem bytowania”). Wojtyła podkreśla:

Człowiek jest niewątpliwie nade wszystko podmiotem swego istnienia i działania, jest tym podmiotem jako byt określonej natury, co ma swe konsekwencje właśnie w działaniu. Ów podmiot istnienia i działania, jakim jest człowiek, tradycyjna ontologia określa mianem suppositum ${ }^{7}$.

Co więcej, możliwości wolności związane są z tym, jak bardzo człowiek jest „upodmiotowiony”, co Wojtyła nazywa „strukturami «samo-posiada-

${ }^{4}$ A. Półtawski, Fenomenologia i patologia wolności. Henri Ey i Karol Wojtyła, „Kwartalnik Filozoficzny", red. W. Stróżewski, t. XXXVIII, 2010, z. 2, s. 26.

${ }^{5}$ K. Wojtyła, Podmiotowość..., s. 440.

${ }^{6}$ Por. K. Wojtyła, Osoba: podmiot i wspólnota, [w:] Osoba i czyn..., 378-381. Także na temat zagadnienia wolności jako „danej”: J. Galarowicz, Człowiek jest osobq̨: podstawy antropologii filozoficznej Karola Wojtyły, Kraków 1994, s. 192.

${ }^{7}$ K. Wojtyła, Osoba i czyn..., s. 93. 
nia» $\mathrm{i}$ «samo-panowania»"8. Podmiotowy charakter osoby sprawia także, że wolność staje się przede wszystkim narzędziem kształtowania samego siebie: „Aby być wolnym, trzeba stanowić konkretne «ja», które będąc podmiotem, równocześnie jest owym pierwszym przedmiotem, o jakim stanowimy aktem woli" . Filozof upatruje obszar autokreacyjnej roli wolności w moralności dokonując wyborów moralnych, człowiek określa siebie poprzez wartości dobre lub złe.

Posługując się kategoriami Wojtyły, można powiedzieć, że Sartre, traktując jako punkt wyjścia dorobek fenomenologii, również kieruje się w stronę myślenia innego niż kosmologiczne. W odróżnieniu jednak od chrześcijańskiego myśliciela, zupełnie przekreśla klasyczny typ refleksji, jako uwikłany $\mathrm{w}$ trudności dualizmu. Zwracając się ku fenomenologii, autor Bytu i nicości wybiera bardziej radykalne rozwiązanie i zakłada, że „zjawisko nie odsyła do bytu" ${ }^{10}$, a jedynie znajduje się w pewnej relacji do ludzkiej wolności. Sartre dostrzega problem nieredukowalności człowieka do świata rzeczy - natomiast „puste miejsce”, stanowiące u Wojtyły jednocześnie przestrzeń osoby i metafizyczne suppositum, u francuskiego filozofa pozostaje nicością, określająca świadomość bytu-w-sobie (jednostki). Wolność świadomości, wymykającej się totalności bytu-w-sobie (bytu przedmiotowego), polega na ruchu „nicościowania” (neantyzacji) od świadomości do przedmiotu: „Byt-dla-siebie nie jest niczym innym, jak czystym nicościowaniem bytu-w-sobie; jest jak bytowa szczelina wewnątrz Bytu [au sein de l'Etre]"11. W szczelinie tej nie ma miejsca na jakąkolwiek substancjalność, a więc również na personalistycznie rozumiany byt osobowy. Postulowane przez Wojtyłę suppositum należałoby tutaj do świata przedmiotów, bytu-w-sobie, z punktu widzenia omawianego egzystencjalizmu będąc czymś „nie-ludzkim” (a nawet, co poniekąd słuszne w odniesieniu do wizji chrześcijańskiej, „boskim” - a więc dla Sartre’a sprzecznym w sobie). Konsekwencją uniezależnienia wolności od metafizycznej podmiotowości jest u Sartre’a zastąpienie zasady operari sequitur esse słynnym twierdzeniem l'existence précède l'essence („,istnienie poprzedza istotę"12).

${ }^{8}$ Por. tamże, s. 152. Także: K. Wojtyła, Natura ludzka jako podstawa formacji etycznej, [w: ",Aby Chrystus się nami postugiwał”, wyb. i układ J. Hennelowa, Kraków 2009, s. 459-460.

${ }^{9}$ K. Wojtyła, Osoba i czyn..., s. 165.

${ }^{10}$ J.-P. Sartre, Byt i nicość. Zarys ontologii fenomenologicznej, przeł. J. Kiełbasa, P. Mróz, R. Abramciów, R. Ryziński, P. Małochleb, Kraków 2007, s. 8.

11 Tamże, s. 757.

12 J.-P. Sartre, Egzystencjalizm jest humanizmem, przeł. J. Krajewski, Warszawa 1998, s. 23. 
Mimo powyższych różnic, warto podkreślić, że akcentowanie ludzkiej wolności jako elementu decydującego o wyjątkowości człowieka pośród świata rzeczy i innych bytów (a więc jest ona postrzegana jako różnica antropologiczna) jest wspólnym rysem dla obu myślicieli. Pozwoliło to na przykład użyć Janowi Pawłowi II słów, których stylistyka bardzo zbliża się do języka autora Bytu i nicości ${ }^{13}$ :

[...] „szczelina” bytu otwierająca człowieka w stronę nieskończoności - to właśnie wolność. Bez wolności człowiek byłby bytem zamkniętym w świecie przyrody - i pozbawionym (właściwej sobie) transcendencji. Byłby równocześnie bytem skończonym i „wykończonym”, zdeterminowanym do końca i wraz $\mathrm{z}$ całą przyrodą ożywioną poddanym bez reszty właściwym dla niej granicom życia, czyli konieczności śmierci ${ }^{14}$.

Obaj filozofowie sprzeciwiają się determinizmowi - o ile jednak Wojtyła włącza w swoje inspiracje fenomenologią (a zwłaszcza wątek ustanawiania przez „ja” samego siebie jako przedmiotu) możliwość metafizycznego fundamentu, Sartre niezwykle mocno radykalizuje pojęcie wolności, dając mocny wyraz postępującemu w filozofii zachodniej „słabnięciu metafizyki”.

\section{Aksjologia i autokreacja}

Według francuskiego egzystencjalisty świadomość nie potrzebuje żadnego fundamentu, ponieważ sama jest absolutem. Jak zaznacza filozof: „[... ] właśnie dlatego, że jest czystym zjawiskiem, że jest całkowitą pustką (ponieważ cały świat jest poza nią), z racji zachodzącej w niej tożsamości zjawiska i istnienia, świadomość może być uważana za absolut"15. Jednak posiada ona taki charakter nie w znaczeniu klasycznym, realistycznym (charakterystycznym m.in. dla tomizmu), ale jako absolut egzystencjalny, pozbawiony wymiaru substancjalnego ${ }^{16}$. To jedyny rodzaj absolutu, jaki dopuszcza koncepcja autora Bytu i nicości, uznając Boga jako niemożliwą do zaistnienia syntezę bytu-

\footnotetext{
${ }^{13}$ Por. np. podobne sformułowania o „szczelinie bytu” w: J.-P. Sartre, Byt i nicość..., s. 591.

${ }^{14}$ Jan Paweł II, Wolność, wyb. cytatów T. Gołąb, autorzy tekstów G. Polak i in., Warszawa 2008, s. 8.

${ }^{15}$ J.-P. Sartre, Byt i nicość..., s. 18.

${ }^{16}$ Por. tamże.
} 
-w-sobie i bytu-dla-siebie, a więc totalności przedmiotowej i świadomościowej wolności ${ }^{17}$.

Odbiciem niezwykle mocnej pozycji świadomości w systemie ontologicznym Sartréa jest przekonanie, że byt-dla-siebie posiada moc ustanawiania wartości (w ramach podmiotowego projektu) i w ustanawianiu tym jest całkowicie suwerenny:

[...] ontologia i psychoanaliza egzystencjalna [...] muszą odkryć przed czynnikiem moralnym to, że jest on bytem, poprzez który istnieja wartości. Wtedy właśnie jego wolność nabierze świadomości siebie samej i odkryje się w lęku jako jedyne źródło wartości, i nicość, poprzez którą istnieje świat ${ }^{18}$.

Ponieważ wartości są ustanawiane przez wolność i pozostają w obszarze neantyzującej świadomości, nie mogą posiadać bytu realnego ${ }^{19}$. Nie mogą także zobowiązywać nikogo poza tym, kto je określa. Jak wyjaśnia filozof w dziele Egzystencjalizm jest humanizmem, definiowanie wartości poprzez uzależnienie ich od świadomości jest jedną z konsekwencji prymatu egzystencji, jako nieposiadającej „sensu a priori”, nad esencją ${ }^{20}$. Niemniej jednak, właśnie z tego powodu często zarzucano filozofii francuskiego myśliciela, że prowadzi do praktycznego nihilizmu, a próby uzasadnienia w Bycie i nicości konieczności podejmowania odpowiedzialności za swoje czyny są niewystarczające.

Warto zauważyć, że jak u Sartre’a neantyczny charakter świadomości przekłada się na sposób istnienia wartości, tak również u polskiego filozofa specyfika bytowania „czynnika moralnego” (czyli osobowego podmiotu) określa aksjologiczny byt. To, co Sartre sytuował w sferze negatywności, Wojtyła zalicza do sfery bytu realnego:

\footnotetext{
${ }^{17}$ Nie uwalnia to wszak ontologii Sartre’a od trudności związanych z istnieniem absolutu. Jak trafnie zauważa Stefan Sarnowski, komentując Byt i nicość: „W dziele tym istnieje pewne wewnętrzne napięcie. Jego źródłem jest, z jednej strony, właśnie poddawanie się owemu projektowi tradycyjnej metafizyki, $z$ drugiej zaś - próby eliminowania go. Mamy oto główny powód, ze względu na który egzystencjalizm Sartre’a może być atakowany za swoją "metafizyczność" ( $w$ pejoratywnym tego słowa znaczeniu, w którym metafizyka jest przeciwieństwem dialektyki) np. ze strony marksistów, lecz także za metafizyczną niepełność - ze strony np. tomistów" (S. Sarnowski, Zmierzch absolutu? Z problemów filozofii chrześcijańskiej i egzystencjalistycznej, Warszawa 1974, s. 150).

${ }^{18}$ J.-P. Sartre, Byt i nicość..., s. 768.

${ }^{19}$ Por. tamże, s. $138-141$.

${ }^{20}$ Por. J.-P. Sartre, Egzystencjalizm..., s. 7.
} 
Czyn i wartości moralne przedmiotowo należą do realnego podmiotu, którym jest człowiek jako ich sprawca, w sposób równie realny i egzystencjalny [...]. Równocześnie zarówno czyn, jak i odpowiadające mu wartości moralne, dobro czy zło, funkcjonują [...] na wskroś podmiotowo w przeżyciu ${ }^{21}$.

Są składnikami, które kształtują moralność osoby - a ściślej mówiąc, to ona kształtuje ją poprzez samostanowienie.

Mimo tego, że koncepcja Wojtyły, podobnie jak egzystencjalizm Sartre’a, akcentuje zdolność człowieka do samookreślania się, w zasadniczy sposób odbiega od myśli francuskiego filozofa. Bardzo istotną kwestią jest tu uprzedzający charakter wartości moralnych, które według autora Osoby i czynu nie są stwarzane, ale wybierane, a przez to uznawane za „swoje” - ich wybór jest zawsze odpowiedzią, dokonującą się w wolności. Warunkiem wyboru jest ich wcześniejsze poznanie, u Sartre’a natomiast poznawany w sensie ścisłym może być tylko byt-w-sobie, do którego wartości nie należą. Za Galarowiczem powiedzieć można, że twierdzenie o spełnianiu się wartości w czynie

[...] nie jest równoznaczne $\mathrm{z}$ twierdzeniem głoszącym, że człowiek jest miarą wszystkich rzeczy, źródłem wartości i stwórcą samego siebie. Wojtyła jest daleki od takiej koncepcji człowieka i ludzkiej wolności, której współtwórcami są: Protagoras, Pico della Mirandola, Marks i Sartre. Koncepcja wolności twórczej Wojtyły jest pokrewna tym teoriom, które uznają twórczy współudział człowieka w ostatecznym ukształtowaniu siebie. Ten współudział polega na tym, że człowiek kreuje siebie jako istotę dobrą lub złą pod względem moralnym ${ }^{22}$.

Moralne stanowienie o-sobie jest jedną z najważniejszych zdolności, konstytuujących personalistyczny charakter bytu.

W koncepcji Sartre’a mamy natomiast do czynienia z poważną trudnością właśnie w związku z zagadnieniem samookreślenia. Jest to istotne tym bardziej, że światopogląd egzystencjalistyczny często kojarzony jest $\mathrm{z}$ ideałem twórczej wolności i świadomej autokreacji. Tymczasem neantyczny charakter bytu-dla-siebie wyklucza jakiekolwiek trwanie dokonywanych wyborów wartości. Oderwanie istnienia od istoty sprawia, że znika „materia” twórczości, a z postulowanej kreacji pozostaje jedynie anihilacja. Trafnie wskazał na tę tendencję Józef Tischner: „Cóż może być racją negatywności? Tylko nicość. Ale co w ten sposób uzyskał [Sartre - M. K.]? Myślę, że nic poza możli-

\footnotetext{
${ }^{21}$ K. Wojtyła, Osoba i czyn..., s. 97.

${ }^{22}$ J. Galarowicz, dz. cyt., s. 200.
} 
wością niszczenia i samozniszczenia. Taka wolność nie jest niczym innym jak «mocą niszczącą», która mówi «nie»"23. Dodać należy, że jednym z modnych trendów współczesnej kultury, które można wywodzić z nurtu egzystencjalistycznego, jest pojmowanie wolności jako swobody kontestacji. Element ten jest zresztą obecny w postaci idei buntu także u innego egzystencjalisty ateistycznego - Alberta Camusa.

W filozofii personalistycznej punkt wyjścia dla człowieka-współtwórcy-siebie stanowi podmiotowość człowieka, wraz z całym bogactwem struktur osobowych, takich jak emocjonalność czy habitualność, które są obszarami kształtowanymi przez wolność (tak jak opisana już moralność). Wojtyła mówi o wolności jako „zadaniu”, (podczas gdy dla Sartre’a jest ona po prostu istniejąca), wskazując na to, że człowiek ma wpływ na to, jaką treścią wypełni swój osobowy byt (w znaczeniu zarówno istoty, jak i istnienia). Galarowicz ujmuje to tak: „[...] wolność fundamentalna jest dana i zadana, jest darem i trudem. Mamy tu do czynienia ze «spiralą hermeneutyczną»: jedno warunkuje drugie i jedno jest przez drugie pogłębiane" ${ }^{24}$. Konsekwencją takiego przekonania jest pozytywny stosunek do egzystencji: człowiek, bytując jako wolne "ja" oraz poprzez struktury samo-panowania i samo-posiadania, a także posiadając zdolność samostanowienia, ze swoją wolnością jest „u siebie”25.

\section{Prawda osoby, prawda świadomości}

Uznanie zadaniowego charakteru wolności ludzkiej kieruje refleksję na problem właściwego rozpoznania wartości, a więc na tematykę epistemologiczną - na czele z pytaniem o prawdę. Na gruncie filozofii Wojtyły wartość ta ma w związku z wolnością znaczenie decydujące ${ }^{26}$. W przywiązaniu do prawdy wyraża się rozumność osoby, która oprócz woli jest jej głównym aspektem. Jest także czynnikiem konstytuującym świadomy charakter czynu:

\footnotetext{
${ }^{23}$ J. Tischner, Spór o istnienie człowieka, Kraków 2001, s. 296.

${ }^{24}$ J. Galarowicz, dz. cyt., s. 201.

${ }^{25}$ Por. tamże, s. 205.

${ }^{26}$ Por. J. Tischner, Myślenie według wartości, Kraków 1994, s. 209-211; J. Galarowicz, Paradoks egzystencji etycznej. Inspiracje: Ingarden - Wojtyła - Tischner, Kraków 2009, s. 172-176; tenże, Człowiek jest osobq..., s. 213-215.
} 
Moment prawdy zawarty w samej istocie rozstrzygania czy też wybierania stanowi $[\ldots]$ o dynamizmie właściwym osobie jako takiej. Moment prawdy wyzwala samo agere osoby i najgłębiej stanowi o rozgraniczeniu tegoż agere od pati, działania od dziania się, jakiego osoba w różny sposób bywa podmiotem ${ }^{27}$.

Otwarcie na prawdę to zwrócenie się ku rzeczywistości, podjęcie ciężaru realizowania wolności przy wymaganiach realności. Jest zatem kolejnym przeżyciem afirmacji, w którym zewnętrzność (świat dany jako prawdziwy) integruje się z wewnętrzną dynamiką osoby, co, jak zaznacza Wojtyła, jest źródłem szczęśliwości osoby.

Filozofia Sartre’a zastępuje kategorie prawdy i nieprawdy pojęciami „dobrej wiary” i „złej wiary”. Zwłaszcza temu drugiemu fenomenowi poświęca na kartach Bytu i nicości wiele miejsca, określając go jako „ucieczkę od tego, czym się jest”. Według filozofa ,już sam projekt ucieczki odsłania przed złą wiarą rozpadanie się bytu w samym jego wnętrzu, i właśnie takiego rozpadu zła wiara pragnie"28. Dobrą wiarą należałoby zatem nazwać podjęcie ciężaru wolności, tego, kim się jest. Sartre skłania się jednak ku temu, że jest ona niemożliwa (jako projekt bytu-w-sobie), a ludzkie istnienie powinno polegać właściwie na samym ruchu od złej do dobrej wiary - to znaczy wysiłku uznawania tożsamości swojego istnienia i podejmowanych wyborów. To dążenie, jako „wierność sobie”, autentyczność (pojęcie rozwijane później szczególnie przez Camusa), jest głównym wyznacznikiem praktycznych implikacji egzystencjalizmu.

Warto zauważyć, że motyw „wewnętrznej szczerości” i autentyczności jest bardzo mocno obecny w chrześcijaństwie. Co więcej, dla Wojtyły właśnie w związku z „wewnętrzną prawdą" władza samostanowienia człowieka jest w istocie niezależna od wszelkich czynników zewnętrznych: „Wolność jest tym, co mnie otwiera ku rzeczywistości - a równocześnie wiąże mnie czysto wewnętrzną zależnością. Jest to zależność od prawdy. Właśnie przez tę zależność od prawdy poznanej i uznanej jestem «niezależny»... niezależny poniekąd od nikogo i od niczego. Zależny wewnętrznie od siebie" ${ }^{29}$. Kwestia ta ściśle wiąże się także z zagadnieniem samo-panowania i samo-posiadania -

\footnotetext{
${ }^{27}$ K. Wojtyła, Osoba i czyn..., s. 187.

${ }^{28}$ J.-P. Sartre, Byt i nicość..., s. 111. Zagadnienie złej wiary dogłębnie analizuje Mary Warnock, w: M. Warnock, Egzystencjalizm, przeł. M. Michowicz, Warszawa 2005, s. 116-125.

${ }^{29}$ Jan Paweł II, Wolność..., s. 8; por. także słowa o „bezsilności” Boga wobec ludzkiej wolności, w: Jan Paweł II, Przekroczyć próg nadziei, Kraków 2006, s. 65; na temat granic groźby zła i zniewolenia także: J. Tischner, Filozofia dialogu, Kraków 2001.
} 
w niezależności ludzkiej indywidualnej wolności wyraża się zasada persona est sui iuris ${ }^{30}$.

Choć wydawać by się mogło, że w tym miejscu obie filozofie się spotykają, koncepcja autora Bytu i nicości znacznie różni się od personalistycznego postulatu związku wolności i prawdy, mimo powierzchownych podobieństw. Można nawet powiedzieć, że punkt ten jest jednym z głównych źródeł sporu między nimi. Wysiłek „dobrej wiary” czy też autentyczności odbywa się bowiem bez odniesienia do rzeczywistości, pozostając jedynie w obszarze świadomości, która, jak już zaznaczono, nie jest bytem substancjalnym. Nie można zatem mówić o jakiejkolwiek prawdzie w znaczeniu realistycznym wolność odnosi się więc de facto do siebie samej, co zamyka egzystencjalistyczną moralność na możliwość jakiejkolwiek transcendencji w wymiarze etycznym (np. w stronę wartości, Boga lub Innego). Co więcej, uznanie takiej transcendencji oznaczałoby według Sartre’a przyjęcie innej postawy zagrażającej świadomości, którą nazywa on "duchem powagi”, zdecydowanie ją krytykując. Filozof podkreśla:

[...] zasadniczym rozwiązaniem psychoanalizy egzystencjalnej ma być doprowadzenie nas do odrzucenia ducha powagi. Duch powagi jest w istocie nacechowany dwojako - rozważa wartości jako dane transcendentne, niezależnie od ludzkiej subiektywności, i przenosi cechę «pożądalności» ze struktury ontologicznej rzeczy do ich zwykłej materialnej treści. [...] Skutkiem ducha powagi, który - jak wiadomo - panuje nad światem, jest doprowadzenie do tego, że za pośrednictwem empirycznych idiosynkrazji nasiąka się wartościami symbolicznymi, tak jak bibuła nasiąka atramentem ${ }^{31}$.

Sartre nie ukrywał nigdy, że za głównego „winnego” opisywanego zjawiska uważał chrześcijaństwo. Warto zauważyć, że właśnie w analizach złej wiary i ducha powagi francuski filozof bardzo mocno ujawnia swoją postawę „mistrza podejrzeń".

Jan Paweł II stanowczo sprzeciwiał się tendencjom filozoficznym, które oddzielałyby wolność od realistycznie pojmowanej prawdy. W encyklice $V e$ ritatis splendor pisze:

[...] w niektórych nurtach myśli współczesnej do tego stopnia podkreśla się znaczenie wolności, że czyni się z niej absolut, który ma być źródłem wartości.

\footnotetext{
${ }^{30}$ Por. K. Wojtyła, Osoba i czyn..., s. 152-153.

${ }^{31}$ J.-P. Sartre, Byt i nicość..., s. 767.
} 
W tym kierunku idą doktryny, które zatracają zmysł transcendencji lub które otwarcie deklarują się jako ateistyczne. [...] Do tezy o obowiązku kierowania się własnym sumieniem niesłusznie dodano tezę, wedle której osąd moralny jest prawdziwy na mocy samego faktu, że pochodzi z sumienia. Wskutek tego zanikł jednak nieodzowny wymóg prawdy, ustępując miejsca kryterium szczerości, autentyczności, «zgody z samym sobą», co doprowadziło do skrajnie subiektywistycznej interpretacji osądu moralnego ${ }^{32}$.

Nietrudno dostrzec w tej wypowiedzi nawiązanie do omówionych poglądów Sartre’a, które często podejmowano później na gruncie ateistycznego egzystencjalizmu. Należy zauważyć, że zastępowanie kategorii prawdy autentycznością jest współcześnie bardzo popularne, zwłaszcza w kulturze Zachodu. Być może przyczyną atrakcyjności idei „wierności sobie” jest właśnie to, że pozornie nie rezygnuje ona z prawdziwości jako wartości (przynajmniej teoretycznie), przez co odróżnia się od całkowitego nihilizmu.

\section{Wolność-W-świecie}

Należy pamiętać, że wolność, podobnie jak wszystko, co należy do bytu-w-sobie, ma u Sartre’a charakter negatywny, nicościujący. Ponieważ filozof rezygnuje z poszukiwania dla ludzkiej wolności oparcia w Bogu („Jesteśmy sami, nic nas nie usprawiedliwi" "33), wiąże się ona z doświadczeniem, które egzystencjalizm nazwał „trwogą" (pojęcie rozwinięte szczególnie w myśli „wczesnego” Heideggera). „Kiedy człowiek uprzytomni sobie pełnię swojej wolności, zaczyna odczuwać cierpienie" 34 - i właśnie ono skłania do przyjęcia postawy złej wiary. Możliwość decydowania staje się zatem ciężarem, a rzeczywistość, przede wszystkim zaś własne „ja”, przestrzenią nieprzyjazną człowiekowi: „[...] jesteśmy skazani na wolność, «rzuceni» w wolność, czy też - jak mówi Heidegger - «opuszczeni», «porzuceni» [...]. To opuszczenie czy porzucenie nie ma zaś, jak widać, innego źródła jak tylko samo istnienie wolności”35. Również wartości, ku którym kieruje się wolność, ze względu

\footnotetext{
${ }^{32}$ Jan Paweł II, Veritatis splendor, [w:] Encykliki Ojca Świętego Jana Pawła II, Kraków 2003, s. 742 .

${ }^{33}$ J.-P. Sartre, Egzystencjalizm..., s. 39.

${ }^{34}$ M. Warnock, dz. cyt., s. 117.

${ }^{35}$ J.-P. Sartre, Byt i nicość..., s. 590.
} 
na nenatyczny charakter nie są możliwe do osiągnięcia, a ludzkie pragnienia nie mogą być zaspokojone - „Człowiek jest daremnym pragnieniem, bezużyteczną ofiarą [une passion inutile]" ${ }^{\prime \prime}$.

Negatywność jako pierwotne doświadczenie świata jest kolejnym aspektem ontologii Sartre’a, który trudno uzgodnić z humanistycznym postulatem twórczego samookreślania się. Należy jednak przyznać, że w stanowisku francuskiego filozofa kryje się przynajmniej część prawdy o dramatyzmie świadomej egzystencji. Zwłaszcza, że do uznania absurdalności ludzkiego bytowania skłaniały okrucieństwa totalitaryzmów, w których ujawniła się w straszliwy sposób negatywna strona wolności.

Trudności tej negacji stara się przezwyciężyć filozofia dialogu, ukazując pierwotność wspólnoty ze światem jako „sceną” dramatu ludzkiej wolności (według wyrażenia Tischnera), na której człowiek zadomawia się, zakorzenia, uświęca - a przede wszystkim spotyka Drugiego ${ }^{37}$. Ludzką zdolność decydowania i wybierania dialogicy postrzegają jako dar, dzięki któremu możliwe jest przyjście z pomocą ludzkiej biedzie ${ }^{38}$. Personalizm Wojtyły również uznaje $\mathrm{w}$ wolności wartość pozytywną. W Osobie i czynie ujmuje jednak problem od innej strony, niż czyni to filozofia dialogu, koncentrując się przede wszystkim na znaczeniu tej wartości dla samej działającej osoby oraz na aspektach ontologicznych, oprócz „daru” (w którym wysuwa na pierwszy plan jego „współdecydowanie” o godności człowieka ${ }^{39}$ ) wskazuje także na wolności jako „zadanie do urzeczywistnienia”. Według Galarowicza „Wojtyła rozróżnia dwa poziomy życia, dwa jego wymiary: wymiar daru i wymiar powinności. Podkreśla przy tym, że wymiar daru jest bardziej podstawowym, głębszym i wyższym poziomem życia”40. Wolność jako dar i wolność jako przekleństwo - jest to jedna z opozycji, które najdobitniej wyrażają różnicę między personalizmem a ontologią Sartre’a.

\footnotetext{
${ }^{36}$ Tamże, s. 756.

${ }^{37}$ Por. J. Tischner, Filozofia dramatu..., s. 220-234.

${ }^{38}$ Por. tamże, s. 60-61.

${ }^{39}$ Por. J. Galarowicz, Paradoks egzystencji etycznej..., s. 179.

${ }^{40}$ J. Galarowicz, Człowiek jest osoba..., s. 193; por. także: K. Węglarczyk, Paradoksy wolności w myśli Jana Pawła II, źródło internetowe: http://www.teologiapolityczna.pl/index.php? optio$\mathrm{n}=$ com_content $\&$ task=view\& id=809\&Itemid $=113$.
} 


\section{Wolność w spotkaniu z wolnością}

Z pewnością obie koncepcje głęboko różni także problematyka Innego. Tu również filozofia autora Bytu i nicości przesycona jest negatywnością. Jego słynne zdanie „Piekło to inni” (z dramatu Przy drzwiach zamkniętych) znacząco określa egzystencjalistyczną optykę patrzenia na relacje międzyludzkie. Wolność, jaką jestem ja sam, spotyka się z wolnością drugiego człowieka jednak skoro, jak już powiedziano, jest ona absolutem, w spotkaniu tym musi nastąpić zniesienie wolności jednej ze stron. Dokonuje się ono poprzez "uprzedmiotawiające spojrzenie" ${ }^{41}$, poznawcze odniesienie bytu-dla-siebie ku innemu, przekształcające go w byt-w-sobie. Jest to jedyne możliwe odniesienie, ponieważ świadomość porusza się jedynie wśród doświadczenia własnego „ja” i jego przeżyć ${ }^{42}$, nie posiada zaś żadnego doświadczenia innego-jako-ja. Tak radykalne postawienie problemu eliminuje możliwość tworzenia z drugim człowiekiem jakiejkolwiek wspólnoty. Dlatego też egzystencjalizm Sartre’a jest postrzegany jako filozofia indywidualizmu. Ze względu na absolutny charakter przyznawany świadomości pozostaje ona w stałym niebezpieczeństwie popadnięcia w solipsyzm, wspomnianą już totalność „ja”. Jak zauważa Emmanuel Mounier (co w pewnym sensie podsumowuje wnioski z poprzednich analiz): „[...] problem komunikacji pozostaje dla egzystencjalistów podstawową trudnością: komunikacja istniejącego $\mathrm{z}$ bytem, $\mathrm{z}$ bytem świata, z bytem drugiego człowieka" ${ }^{3}$. Sartre’owska świadomość pozostaje istnieniem zamkniętym wobec innego - nieprzeniknioną totalnością, będąc jednocześnie absolutną wolnością. Warto zauważyć, że tym samym zarzut, który filozof odnosił do chrześcijańskiej koncepcji Boga, uderza tutaj w postulowany przez niego absolut świadomościowy.

Wojtyła poddał fenomen bycia-z-innymi gruntownej analizie etycznej głównie w tekstach Miłość i odpowiedzialność oraz Uczestnictwo czy alienacja? U polskiego filozofa kluczowe dla tematu relacji międzyludzkich jest to, że wymiar daru odzwierciedla całość dynamiki ludzkiego bytu. Wolność rozumiana jest przez niego jako środek dla realizacji miłości (filozof stwierdza

\footnotetext{
${ }^{41}$ Studium spojrzenia przeprowadza Sartre, w: J.-P. Sartre, Byt i nicość..., s. 326-388.

${ }^{42}$ Tamże, s. 301.

${ }^{43}$ E. Mounier, Perspektywy egzystencjalistyczne i perspektywy chrześcijańskie, [w:] tenże, Wprowadzenie do egzystencjalizmów oraz wybór innych prac, przeł. E. Krasnowolska, Kraków 1964.
} 
nawet, że „człowiek pragnie miłości bardziej niż wolności” ${ }^{44}$ - a więc „darowania siebie drugiemu", również rozpoznawanemu i afirmowanemu jako wartość. Spotkanie jest zatem szansą na pełną realizację siebie jako osoby, nie zaś zagrożeniem utraty własnej podmiotowości. Inaczej niż Sartre, Wojtyła stara się przekroczyć granicę doświadczenia zawartego w przeżyciu „ja”: „[...] niemożliwość przeniesienia w sposób doświadczalny poza siebie tego, co stanowi własne «ja», nie oznacza niemożliwości zrozumienia, że «drugi» jest ukonstytuowany podobnie, że jest on także jakimś «ja»" ${ }^{5}$.

Konkretne, niepowtarzalne spotkanie, przeżycie „innego «ja»” jako osoby obdarzonej niezależną ode mnie dynamiką wolności, umożliwia wyjście poza odniesienie poznawcze (którego przedmiotem byłby inny jako „człowiek") w stronę uczestnictwa: po pierwsze, uczestnictwa drugiego w człowieczeństwie, a po drugie - bytowania i działania wspólnie z nim ${ }^{46}$. Inaczej niż u Sartréa, mamy tu do czynienia z koncepcją wolności jako otwartej wobec innych - jej upodmiotowienie $w$, ja” oraz uznanie w ,innym ja” umożliwia współistnienie wolności. Wojtyła zaznacza, że inicjacja uczestnictwa nie jest czymś spontanicznym, ale wymaga aktywności ze strony podmiotu. Praktyczny wybór między personalizmem a egzystencjalizmem Sartre’a jest więc m.in. wyborem pomiędzy zaangażowanym uczestnictwem a zdystansowaniem się wobec świata, szczególnie zaś wobec wolności innych.

Można powiedzieć, że tę dwoistość odzwierciedla społeczno-historyczny kontekst obu antropologicznych projektów. Dla personalizmu w Polsce istotne okazały się losy totalistycznych struktur w powojennej Europie i zniewolenie przez komunizm - specyficzna sytuacja, która nie zdarzyła się we Francji (przeżywającej odrodzenie etyki indywidualistycznej w różnorakich postaciach). W ojczyźnie Wojtyły główną rolę w politycznych przemianach i odzyskaniu wolności odegrał nie indywidualizm, ale potężny „ruch uczestnictwa” - którego wyrazem była przede wszystkim „Solidarność”. Wojtyła, również jako Jan Paweł II, wspierał aktywnie dążenia integrujące ludzi we wspólnotach, wcielając w swoje nauczanie to, co wcześniej wyrażał w tekstach filozoficznych. „Uczestnictwo” stało się więc kluczem do odzyskania wolności. Jak podkreśla Jan Paweł II w Pamięci i tożsamości, jest również drogą do jej zachowania:

${ }^{44}$ K. Wojtyła, Miłość i odpowiedzialność, red. T. Styczeń, J. W. Gałkowski, A. Rodziński, A. Szostek, Lublin 2001, s. 120.

${ }^{45} \mathrm{~K}$. Wojtyła, Uczestnictwo czy alienacja?, [w:] Osoba i czyn oraz inne studia antropologiczne, red. T. Styczeń, W. Chudy, J. W. Gałkowski, A. Rodziński, A. Szostek, Lublin 2000, s. 450.

${ }^{46}$ Tamże, s. 458. 
Jeżeli po upadku systemów totalitarnych społeczeństwa poczuły się wolne, to prawie równocześnie zrodził się inny podstawowy problem - problem użycia wolności. A problem ten ma wymiar nie tylko indywidualny, ale także zbiorowy. Domaga się on rozwiązania niejako systemowego ${ }^{47}$.

Owa „systemowość” wyraża się w tym, co papież określa „strukturami miłości” przeciwstawianymi „strukturom grzechu” - co ma wskazywać na konieczność trwałego umocowania podmiotowej wolności w instytucjach społecznych.

\section{Dwie narracje ludzkiej wolności}

Obie koncepcje łączy koncentracja na wolności i uznanie, że ma ona decydujące znaczenie dla podmiotowości człowieka. Obie dochodzą jednak do radykalnie różnych wniosków - o ile Sartre podąża drogą negatywności, by postawić ludzką wolność w miejscu, w którym klasyczna filozofia stawiała Absolut, gdzie prowadzi on nieustanną grę o zachowanie swojej suwerenności, o tyle Wojtyła upatruje istotę ludzkiej egzystencji w zakorzenieniu w bycie i otwarciu - nie tylko na drugiego człowieka, ale także na Boga. Opisywane nurty (a tym samym - wzajemnie nieredukowalne narracje antropologiczne) odzwierciedlają różne rodzaje ludzkiego doświadczenia wolności w którym mieści się rozpaczliwa walka o autonomię, próby rozbicia „muru” ograniczeń narzucanych przez ideologie, instytucje i drugiego człowieka, a $\mathrm{z}$ drugiej strony - ich afirmacja oraz wspólnotowe uczestnictwo i zaangażowanie. Po tak różnych wizjach antropologicznych, jak filozofie Wojtyły i Sartre’a trudno oczekiwać, choć istnieją pewne zbieżności, wejścia w jakiś wspólny dyskurs. Jednak mimo wszystko ich przeciwstawianie, a zwłaszcza konfrontowanie z ludzkim przeżywaniem, może być bardzo interesującym kierunkiem rozwoju refleksji filozofii wolności.

\footnotetext{
${ }^{47}$ Jan Paweł II, Pamięć i tożsamość..., s. 41.
} 


\section{Bibliografia}

\section{Karol Wojtyła / Jan Paweł II - dzieła:}

Jan Paweł II, Pamięć i tożsamość, Kraków 2005.

Jan Paweł II, Przekroczyć próg nadziei, Kraków 2006.

Jan Paweł II, Veritatis splendor, [w:] Encykliki Ojca Świętego Jana Pawła II, Kraków 2003, s. 703-838.

Jan Paweł II, Warszawa, 9 czerwca 1991 r. - Homilia w czasie Mszy św. beatyfikacyjnej ojca Rafała Chylińskiego, [w:] Homilie i przemówienia z pielgrzymek: Europa, Cz. 1: Polska, red. Paweł Ptasznik i in., Kraków 2008, s. 571-575 (Dzieła zebrane, t. IX).

Jan Paweł II, Wolność, wyb. cytatów Tomasz Gołąb, Warszawa 2008.

Wojtyła K., Elementarz etyczny, [w:] „Aby Chrystus się nami posługiwat”, wyb. i układ Józefa Hennelowa, Kraków 2009, s. 138-192.

Wojtyła K., Natura ludzka jako podstawa formacji etycznej, [w:] „Aby Chrystus sie nami posługiwał”, wyb. i układ Józefa Hennelowa, Kraków 2009, s. 455-460

Wojtyła K., Miłość i odpowiedzialność, red. Tadeusz Styczeń, Jerzy W. Gałkowski, Adam Rodziński, Andrzej Szostek, Lublin 2001.

Wojtyła K., Osoba i czyn, [w:] Osoba i czyn oraz inne studia antropologiczne, red. Tadeusz Styczeń, Wojciech Chudy, Jerzy W. Gałkowski, Adam Rodziński, Andrzej Szostek, Lublin 2000, s. 43-344.

Wojtyła K., Osoba: podmiot $i$ wspólnota, [w:] Osoba i czyn oraz inne studia antropologiczne, red. Tadeusz Styczeń, Wojciech Chudy, Jerzy W. Gałkowski, Adam Rodziński, Andrzej Szostek, Lublin 2000, s. 371-414.

Wojtyła K., Podmiotowość i „to, co nieredukowalne” w człowieku”, [w:] Osoba i czyn oraz inne studia antropologiczne, red. Tadeusz Styczeń, Wojciech Chudy, Jerzy W. Gałkowski, Adam Rodziński, Andrzej Szostek, Lublin 2000, s. 433-443.

Wojtyła K., Uczestnictwo czy alienacja?, [w:] Osoba i czyn oraz inne studia antropologiczne, red. Tadeusz Styczeń, Wojciech Chudy, Jerzy W. Gałkowski, Adam Rodziński, Andrzej Szostek, Lublin 2000, s. 446-461.

$$
\text { Jean-Paul Sartre - dzieła: }
$$

Sartre J.-P., Byt i nicość. Zarys ontologii fenomenologicznej, przeł. Jan Kiełbasa, Piotr Mróz, Rafał Abramciów, Remigiusz Ryziński, Paulina Małochleb, Kraków 2007. Sartre J.-P., Egzystencjalizm jest humanizmem, przeł. Janusz Krajewski, Warszawa 1998. 


\section{Pozostałe:}

Galarowicz J., Blask godności. O etyce Karola Wojtyty i nie tylko, Kęty 2005.

Galarowicz J., Człowiek jest osoba: podstawy antropologii filozoficznej Karola Wojtyły, Kraków 1994.

Galarowicz J., Paradoks egzystencji etycznej. Inspiracje: Ingarden - Wojtyła - Tischner, Kraków 2009.

Kupczak J. OP, Destined for Liberty. The Human Person in the Philosophy of Karol Wojtyła/John Paul II, Washington D.C. 2000.

Mounier E., Perspektywy egzystencjalistyczne i perspektywy chrześcijańskie, [w:] Emmanuel Mounier, Wprowadzenie do egzystencjalizmów oraz wybór innych prac, przeł. Ewa Krasnowolska, Kraków 1964.

Possenti V., Filozofia i wiara, przeł. Katarzyna Kubis, Kraków 2004, s. 24

Półtawski A., Fenomenologia i patologia wolności. Henri Ey i Karol Wojtyła, „Kwartalnik Filozoficzny", red. Władysław Stróżewski, t. XXXVIII, 2010, z. 2, s. 25-38.

Sarnowski S., Zmierzch absolutu? Z problemów filozofii chrześcijańskiej i egzystencjalistycznej, Warszawa 1974.

Tischner J., Filozofia dialogu, Kraków 2001.

Tischner J., Myślenie według wartości, Kraków 1994

Tischner J., Spór o istnienie człowieka, Kraków 2001.

Warnock M., Egzystencjalizm, przeł. Monika Michowicz, Warszawa 2005.

Węglarczyk K., Paradoksy wolności w myśli Jana Pawła II, [źródło internetowe:] http:// www.teologiapolityczna.pl/index.php? option=com_content\& task=view\& id= 809\&Itemid=113.

Wilk R. K., Metodologia antropologii filozoficznej Karola Wojtyły, „Kwartalnik Filozoficzny", red. Władysław Stróżewski, t. XXXVIII, 2010, z. 2, s. 39-61.

\section{Abstract}

\section{Person and Nothingness. The Question of Freedom According to John Paul II and Jean-Paul Sartre}

The paper concerns a comparison of concepts of freedom from personalist (Karol Wojtyła's philosophy) and existentialist discourses (represented by Jean-Paul Sartre). It aims to show their common places and differences, as well as to place them in a wider context of transformation of the Western thought. The comparison enables to see, how the Christian philosophy of Person and Act's author, as well as radical project of French philosopher take-part in the crisis of the reflection on subjectivity. It reveals a weakening of traditional anthropology in the Wojtyła's thought, which 
includes elements stressing self-creative role of an individual, a priority of existential projects over preexisting (natural, social, supernatural) schemes, and a hermeneutical relation with the world. On the other hand, one could see also how metaphysical model, based on binary oppositions, affects Sartre, who aimed to erase the idea of a substantial subjectivity from his thought.

Key words: freedom, personalism, existentialism, christianity, ethics, Karol Wojtyła, Jean-Paul Sartre, weak thought 